\title{
Teaching Reform of Obstetrics and Gynecology Nursing Course in Higher Vocational Colleges Based on OBE Education Concept from the Perspective of Big Data
}

\author{
Shanshan Huang ${ }^{1 \#}$, Huifang Chen ${ }^{2 \# *}$, Hua Cao ${ }^{1}$ and Lulu Yan ${ }^{1}$ \\ ${ }^{1}$ School of nursing and health, Guangdong Lingnan Institute of Technology, China \\ ${ }^{2}$ School of pharmacy, Guangdong Lingnan Institute of Technology, China \\ ${ }^{\#}$ Huifang Chen and Shanshan Huang contribute equally
}

*Corresponding author: Huifang Chen, School of pharmacy, Guangdong Lingnan Institute of Technology, Guangzhou, Guangdong Province, 510663, China

ARTICLE INFO

Received: 幽 July 06, 2021

Published: 慧 July 16, 2021

Citation: Shanshan Huang, Huifang Chen, Hua Cao, Lulu Yan. Teaching Reform of Obstetrics and Gynecology Nursing Course in Higher Vocational Colleges Based on OBE Education Concept from the Perspective of Big Data. Biomed J Sci \& Tech Res 37(2)2021. BJSTR. MS.ID.005974.
ABSTRACT

The application of big data puts forward new requirements for the talent training mode and curriculum reform of big data in higher vocational colleges. Through statistical data, the classroom quality can be measured, evaluated and traced. Under the framework of "Internet plus big data", taking the cultivation of innovative ability as the core, realizing the multidimensional integration of technology and science, general knowledge and specialty, teaching and research, and teachers and students has become a new concept and Practice for improving the quality of big data talents training in higher vocational colleges. Obstetrics and gynecology nursing is one of the core courses of nursing specialty in higher vocational colleges, which is of great significance to the cultivation of professional talents. The purpose of nursing specialty in higher vocational colleges is to cultivate skilled and technical applied talents to meet the needs of medical and health posts, which requires the combination of theoretical knowledge and practical skills, so as to cultivate students' clinical thinking and ability. There are some problems in the course design of Obstetrics and gynecology nursing in higher vocational colleges, such as the derailment of theoretical teaching and practical teaching, teaching materials lagging behind the update of clinical skills, students' low learning initiative, single teaching mode and so on. Based on the OBE teaching concept from the perspective of big data, this paper carries out curriculum design, curriculum implementation and Curriculum Evaluation Guided by students' learning achievements, and through the reverse design of achievements, highlights the student-centered, quantifies teaching output, and cultivates students' learning ability and creativity.

By reasonably mobilizing students' learning initiative, students can achieve "selfeducation, self-management, self-service, and common improvement", so as to improve the teaching quality of this course, improve students' clinical skills, promote the selfdevelopment of teachers and students, and realize the "win-win" of education.

\section{Introduction}

Obstetrics and gynecology nursing is one of the core courses of nursing specialty in higher vocational colleges. This course is opened in the third semester, with a total of 3 credits. This course is a key course for students to master before entering gynecology and obstetrics clinic. Through the study of this course, students are required to have solid professional knowledge and proficient 
practical skills. Therefore, this course needs to cultivate students' clinical thinking ability and operation skills through the combination of theoretical knowledge and practical operation. The course team analyzed the current situation of the course of Obstetrics and gynecology nursing in Higher Vocational Colleges by using big data tools and found that the teaching materials of this course are relatively backward; The teaching mode is single; The assessment method is single; Students' learning initiative is weak; The training of theoretical knowledge and practical ability. In this regard, our curriculum group adopted OBE teaching concept to reform the curriculum through comparison and exploration. OBE (outcomesbased education) means that the final results of teaching activities are presented by students' learning outcomes. Students' learning achievement is the maximum ability that students can achieve after a period of learning. Schools and teachers are required to make clear the students' learning achievement, combine the diversified learning process and hierarchical learning requirements, and let students complete the challenge of self-realization through the learning process.

Teachers can feedback and improve the original teaching plan and teaching implementation by using the results. Secondly, the ways of enrollment in higher vocational colleges are diversified, students' learning background is different, and the use of unified teaching materials in different learning situations obviously does not meet the needs of learning situation, which leads to the decline of students' learning initiative and enthusiasm. Therefore, starting from the learning situation, the loose-leaf teaching material is used to deconstruct the knowledge system and framework, reconstruct the knowledge chain, reconstruct the teaching module, and teach at different levels according to the learning situation background. This course takes the female life cycle as the logic of the course and reconstructs the knowledge module of the course; Taking the students as the center, based on the training objectives of the five major learning areas of $\mathrm{OBE}$, the differentiated teaching is designed, and the course implementation is carried out in the same class and heterogeneous way; With students' learning achievement as the guidance, multiple assessment methods coexist and multidimensional assessment is carried out simultaneously; Based on the learning situation, starting from the needs, project-based teaching, students are the main body of the course; Integrated teaching of theory and practice $[1,2]$.

In the course of teaching reform, how to reconstruct the teaching system, optimize the teaching content, improve the teaching methods, standardize the teaching process and improve the teaching evaluation as the main content, it is imperative for us to implement the teaching reform and practice of big data application technology course, and cultivate the compound talents with practical ability and technological innovation ability.

\section{Construction of DQP Academic Framework Under OBE Teaching Concept}

In 1981, American scholar Spady first put forward the concept of achievement-oriented education, and gradually formed a complete education system. The theoretical connotation is that students are the main body, and the ultimate learning achievement of students is the goal. From the setting of teaching objectives to curriculum design, curriculum implementation, curriculum evaluation are all result oriented, and then every link of curriculum implementation is deduced from the results. The DQP model is based on students' learning outcomes. The main structure of DQP is composed of five institution specific areas and three academic levels, namely: professional knowledge, extensive and integrated knowledge, intellectual skills, applied and collaborative learning, citizen and global learning. Among the five learning areas, "extensive and integrated knowledge", "application and collaborative learning", "citizen and global learning" are the three areas emphasized in general education to achieve the teaching effect"Professional knowledge and intellectual skills are the two fields that put more emphasis on the requirements of students' professional knowledge and skills. According to the theory of DQP, the five learning areas in the same level of academic structure combine the differences among different students, which can truly and uniformly reflect the ability evaluation standard. The three academic levels include associate degree, bachelor's degree and master's degree.

The differences in different academic levels mainly reflect the progressive relationship between the reference points of learning achievement requirements in the five major learning fields: the learning achievement requirements of all bachelor's levels include the learning achievements of associate degree, and the learning achievements of all master's levels also include the learning achievements of bachelor and associate degree. The requirements of learning outcomes at each level show the further challenges and skills that students need to deal with when they move from one degree to a higher degree. Through the spider web diagram of the five major learning fields, the unity of the evaluation of each educational level is intuitively reflected; The hierarchy of ability requirements; Comprehensive knowledge support and achievement embodiment [3] Figure 1. Taking the knowledge structure of the five learning fields as the framework template, students can change from "understanding, mastering and memorizing" in the previous curriculum standards to curriculum norms, including the process comprehensive assessment of "being able to say, be able to do, be able to solve, etc. "For example, DQP puts forward that "in a special field or a relatively common field of art and science, when doing a project, writing an article or program, or performing 
a performance, we can effectively find the information we need, classify the collected information, evaluate the usefulness of the information, and properly quote or apply the useful information to the project Article or scheme, performance ".

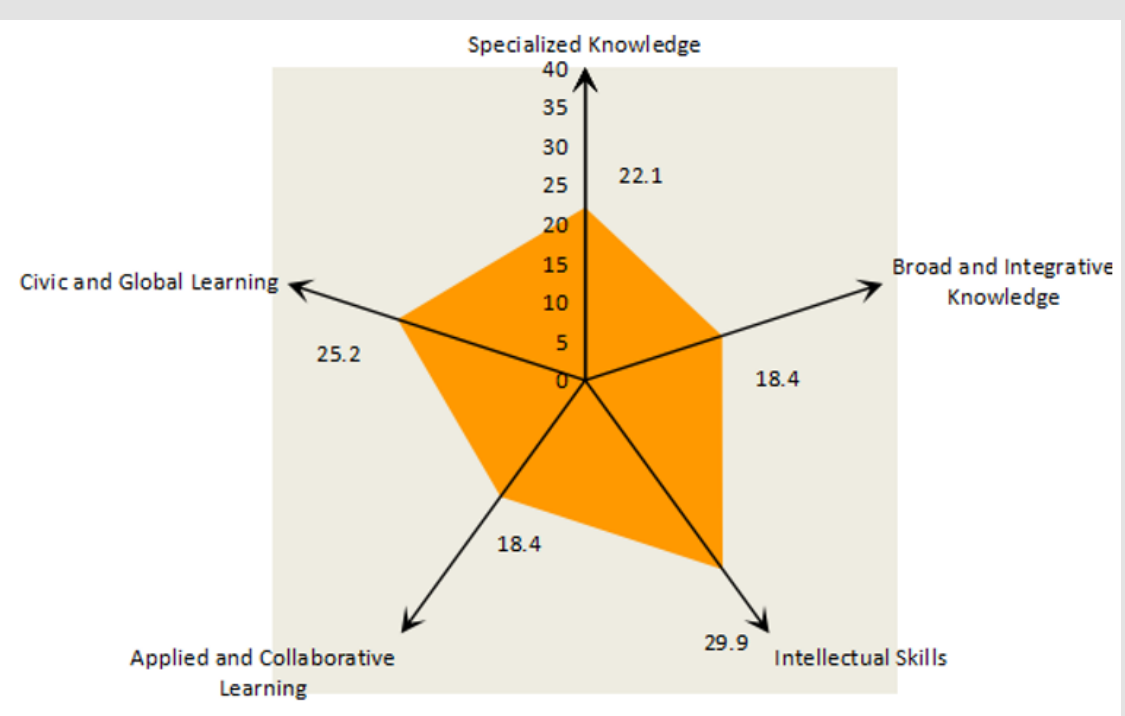

Figure 1: five learning areas.

For example, in order to cultivate students' creative ability, teachers can carry out evidence-based analysis of clinical operation guidelines in the practical training of Obstetrics and gynecology nursing, let students divergent thinking, find evidence through empirical research to support existing views or improve existing views, innovate existing equipment, etc. We should cultivate and incubate valuable research to promote the progress of teachers and students. Students and teachers design together, verify the results together, learn together and grow together [4]. The form of curriculum assessment is not only reflected in knowledge memory and knowledge accumulation, but also focuses on the practicality of knowledge. At the same time, it combines the application and innovation of knowledge, which is well in line with the call of the country for innovation and entrepreneurship. Through the learning process of peer-to-peer curriculum, diversified curriculum achievements are reflected, and students' learning process and skills are deposited in the display of learning achievements, which can be measured, evaluated, further corrected and improved. Verify the learning effect of students and reflect the teaching effect of teachers, so as to reverse design the course and further implement the classroom reform and optimization [5].

Through peer-to-peer learning process, diversified curriculum achievements are reflected, and students' learning process and skills are deposited in the display of learning achievements. Through data comparison and analysis, students' learning achievements can be measured, evaluated, and further corrected and improved. With the development and improvement of information technology, people's learning methods and behavior habits have been gradually changed. The traditional teaching mode has been unable to meet the current teaching needs. Under the perspective of "Internet plus big data", students have more learning means and various learning channels. Nowadays, most of the students in Higher Vocational Colleges grow up in the period of rapid development of information technology. They have a natural curiosity about new things and ideas. Their thinking mode and learning state are very different from those of the past. Through big data technology, students can search most of the content on the Internet. To a certain extent, it has changed the students' learning style, and also provided some new ideas for the curriculum teaching reform in higher vocational colleges. Only by adopting the methods that students can accept, can the curriculum teaching be effectively changed. Through the analysis of statistical data to understand the teaching effect, verify the learning effect of students.

So as to feedback the teaching quality of teachers. Through the analysis and comparison of classroom data, we can reverse design the curriculum and further implement the classroom reform and optimization.

\section{Curriculum Standard of Obstetrics and Gynecology Nursing}

Teaching Content: According to the female life cycle, this course is designed into five modules: basic theory 2 class hours, including female reproductive system anatomy and physiology. 16 hours of gestational care, including pregnancy physiology to start the journey of life, prenatal examination to explore the secret of baby growth, prenatal examination to explore the mother's secret, abnormal pregnancy to reveal the mother's troubles. Childbirth care for 10 hours, including normal childbirth escort, abnormal 
childbirth race against the clock. 16 credits for gynecological diseases, including inflammation of reproductive system, tumor of reproductive system and endocrine diseases. 4 class hours for women's health care.

Analysis of Learning Situation: We get a series of data by using questionnaire survey and other methods, and then use big data analysis method to get the students' learning situation of this course. The specific performance of his learning situation is as follows. The student group of this course is the new generation after zero, which belongs to the third semester of nursing sophomore. This student group not only has the common characteristics of students of this age group, but also has the specific learning situation characteristics of students of this major. First of all, the new generation after 2000 is full of personality and curiosity about new things. They have strong hands-on ability. They don't like to be limited and always have unlimited creativity, but they have certain shortcomings. For example, they are not willing to repeat learning and are not willing to train many times. Secondly, the proportion of male and female in nursing major is very different, female students account for $80 \%-100 \%$ of the class on average, and the classroom activity is relatively low compared with ordinary classroom. In terms of basic knowledge, students have offered systematic anatomy, female physiology and other courses when they enter the course. Because the enthusiasm of students' repeated learning is not high, so the mastery of theoretical knowledge is relatively weak. According to the learning characteristics of students, this course combs the preview before class through mind map and other ways, strengthens the review after class, and reviews the old to learn the new. In terms of basic skills, students have preliminary contact with nursing and obstetrics and Gynecology related skills, but their proficiency is not high.

In this regard, this course carries out situational guidance, optimizes training courses, refines training standards, and improves students' enthusiasm through mutual training and evaluation. At the same time, the learning characteristics of this course are different from other courses. Because most of the students in the class are girls, they are very interested in exploring the secrets of pregnant mothers. It is very important for teachers to take the students' interest as the ignition point, to stimulate the enthusiasm of students' active exploration of learning, and to let the students become the main body of the classroom, active learning. In terms of learning characteristics, students like hands-on operation, but induction and summary, clinical thinking ability need to be improved. Through the project-based curriculum module, this course integrates knowledge and skills into vivid nursing cases and improves students' problem-solving ability through case training. In terms of learning habits, students are willing to try to use intelligent mobile terminal devices to carry out learning, prefer personalized learning tasks, make full use of online teaching resources, carry out hybrid teaching, and respect and promote students' personality development by personalized assessment of learning results. The new generation of post-Zero students have distinctive personality characteristics, strong innovation ability, but poor knowledge transfer ability. Therefore, it is necessary to teach students in accordance with their aptitude, improve classroom participation, and formulate executable training objectives that match the learning situation, which is the embodiment of OBE education concept [6].

\section{Teaching Objectives}

Overall Objective: By using big data analysis tools, we connect the knowledge points and skills of nursing practical jobs with our higher vocational obstetrics and gynecology nursing course, to implement the training program of nursing professionals and the curriculum standard of Obstetrics and gynecology nursing based on the analysis of learning situation. The curriculum design establishes a three-dimensional target system of knowledge, skills and quality, and designs the corresponding program outcome (POC) Figure 2. The objective of this course is to master the obstetrics and Gynecology professional knowledge, cultivate professional skills and promote the ability improvement. The three-dimensional objectives of this course include knowledge objectives, skill objectives and quality objectives. The training objectives of each dimension correspond to and match the relevant learning fields in DQP education framework structure. Knowledge objectives correspond to one credit of PoC1 professional knowledge in five major learning fields. Students can describe the core theories and practices in the field of nursing with relevant terms in the nursing field and solve the nursing problems in the professional field. The skill objectives correspond to the knowledge of poc2, poc3 intelligence, poc4 application and cooperative learning in the five learning fields. Poc2 is 0.5 credits in wide and integrated knowledge. Students can analyze a controversial problem (such as unprotected delivery, clinical treatment without payment ability) with knowledge of core areas learned, explain the clinical significance of the dispute, and explain their own opinions with the knowledge learned. Poc3 has 0.5 credits of intelligence skills and can use the knowledge learned to solve and coordinate the relationship between nurses and patients, medical care and nursing, and propose solutions for specific cases and revise the implementation plan. 


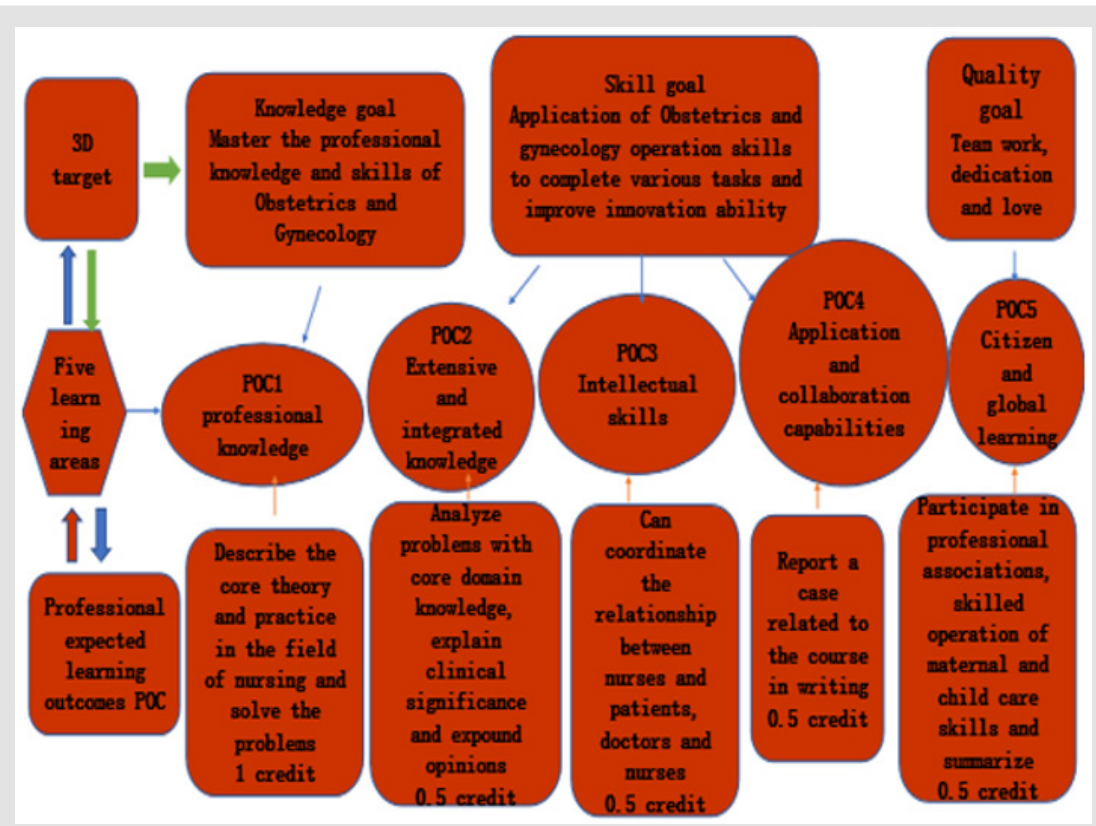

Figure 2: learning target decomposition diagram.

Poc4 application and cooperative learning 0.5 credits, report at least one case related to the course in writing (such as head basin incorrect, multiple pregnancy, etc.) to explain how to apply the knowledge learned to clinical practice and to standardize clinical evaluation standards. The quality goal is 0.5 credits in poc 5 citizens and global learning fields, that is, through the course learning, students participate in the relevant professional associations (including nursing health association and midwifery knowledge association) to skillfully operate maternal and infant nursing skills, make oral or written summary (report), and improve coordination ability, organizational ability and communication ability through organizational activities [6].

Expected Learning Results of Representative Courses: According to the characteristics of nursing specialty, we carry out three-dimensional education of people, and integrate the cultivation and practice of socialist core values into the teaching process of each class, so as to keep things fine and silent. Through the guidance of classroom thinking and politics, we should carry out labor education, life education, humanistic care, etc. In order to support and realize the achievement of POC, the corresponding "subject outcome" (SOC) [7] (Table 1).

Table 1: Comparison of learning outcomes and expected learning outcomes.

\begin{tabular}{|c|c|c|c|}
\hline Number & Content & Credit & Poc \\
\hline SOC1 & Case analysis, complete and accurate summary of abnormal pregnancy patients with clinical \\
manifestations and nursing points & 1 & Poc1 \\
\hline SOC2 & $\begin{array}{c}\text { Group discussion on "whether lateral episiotomy is necessary for natural labor", and clearly } \\
\text { share the views of the group through multimedia equipment }\end{array}$ & 0.5 & POC2 \\
\hline SOC3 & $\begin{array}{c}\text { The patients were divided into two groups to carry out the scene drill of abdominal four step } \\
\text { palpation and mutual evaluation within the group }\end{array}$ & 0.5 & POC2/4 \\
\hline SOC4 & Sitcom, nurse patient relationship Report & 0.5 & POC3 \\
\hline SOC5 & According to the results of SOC1, this paper expounds the health guidance for this kind of \\
patients & 0.5 & POC3/5 \\
\hline
\end{tabular}

Analysis of Key and Difficult Points and Teaching Strategies: Based on the background of learning situation analysis, under the guidance of teaching objectives and professional norms, the focus of this course is to describe the pathogenesis and symptom characteristics of Obstetrics and Gynecology related diseases without error and complete the nursing operation of Obstetrics and Gynecology related diseases without error. We deconstruct and reorganize the curriculum according to the female life cycle and divide the curriculum into five modules. Now take module two pregnancy care as an example to choose the key and difficult points and corresponding teaching strategies (Table 2) [8]. 
Table 2: curriculum modules and teaching strategies.

\begin{tabular}{|c|c|c|c|}
\hline Chapter & Content & Analysis Of Key and Difficult Points & Teaching Method \\
\hline Opening chapter & $\begin{array}{c}\text { Scene1: start the journey of life } \\
\text { nurturing - nursing care of pregnant } \\
\text { women }\end{array}$ & $\begin{array}{l}\text { Key points: } 1 ; 2 \text {. Be able to give health } \\
\text { guidance during pregnancy. } \\
\text { Difficulties: } 1 \text {. Be able to judge the mode } \\
\text { of delivery, fetal presentation and fetal } \\
\text { orientation. }\end{array}$ & $\begin{array}{l}\text { 1.Task driven method } \\
\text { 2.Case analysis }\end{array}$ \\
\hline Exploration (training course) & $\begin{array}{l}\text { Scene2: exploring the secret of growth } \\
\text { prenatal examination }\end{array}$ & $\begin{array}{l}\text { Key points: } 1 . \text { Be able to judge the health } \\
\text { status of pregnant women and fetus } 2 \text {. Be } \\
\text { able to estimate and check the gestational } \\
\text { period or gestational age; } 3 \text {. Be able to } \\
\text { guide the health care of pregnant women } \\
\text { in the first prenatal examination. } \\
\text { Difficulties: } 1 \text {. Be able to judge the health } \\
\text { status of pregnant women and fetus; } 2 \text {. } \\
\text { Be able to master the content of the first } \\
\text { production inspection and the normal } \\
\text { value of each inspection item. }\end{array}$ & $\begin{array}{l}\text { Task driven method. } \\
\text { Case analysis } \\
\text { Research on group } \\
\text { cooperation training }\end{array}$ \\
\hline & $\begin{array}{c}\text { Scene3: exploring the secret of } \\
\text { pregnant mother - extrapelvic } \\
\text { measurement }\end{array}$ & $\begin{array}{l}\text { Key points: } 1 \text {. Be able to judge whether } \\
\text { the pelvis is abnormal. } \\
\text { 2. Be able to analyze the influence of pelvis } \\
\text { on delivery. } \\
\text { Difficulties: } 1 \text {. Be able to judge whether } \\
\text { the pelvis is abnormal; } 2 \text {. Be able to } \\
\text { analyze the influence of pelvis on delivery. }\end{array}$ & $\begin{array}{l}\text { 1.Group cooperation training } \\
\text { 2.Case analysis } \\
\text { 3.Teaching method }\end{array}$ \\
\hline & $\begin{array}{l}\text { Scene4: explore baby's Secret - four } \\
\text { step abdominal palpation }\end{array}$ & $\begin{array}{l}\text { Key points: } 1 \text {. The mode of delivery, fetal } \\
\text { presentation and fetal position were } \\
\text { judged; } 2 \text {. Master the operation points of } \\
\text { abdominal four step palpation. } \\
\text { Difficulties: } 1 \text {. Judge the mode of delivery, } \\
\text { fetal presentation and fetal position; } 2 \text {. } \\
\text { Master the operation points of abdominal } \\
\text { four step palpation. }\end{array}$ & $\begin{array}{l}\text { 1.Case analysis } \\
\text { 2. Task driven method } \\
\text { 3.Teaching method } \\
\text { 4.Group cooperation training } \\
\text { 5. Role playing }\end{array}$ \\
\hline \multirow[t]{3}{*}{ Uncover secrets } & $\begin{array}{c}\text { Scene5: reveals the worries of pregnant } \\
\text { women (nursing care of high-risk } \\
\text { pregnant women) }\end{array}$ & $\begin{array}{c}\text { Key points: } 1 \text { Screening and monitoring } \\
\text { measures of high-risk pregnancy, clinical } \\
\text { manifestations of fetal distress; } 2 \text {. } \\
\text { Principles of management of neonatal } \\
\text { asphyxia. } \\
\text { Difficulties: } 1 \text {. Screening and monitoring } \\
\text { measures of high-risk pregnancy; } 2 \text {. } \\
\text { Clinical manifestations and treatment } \\
\text { principles of neonatal asphyxia. }\end{array}$ & $\begin{array}{l}\text { 1.Teaching method } \\
\text { 2.Task driven method } \\
\text { 3.Case analysis } \\
\text { 4. Role playing }\end{array}$ \\
\hline & $\begin{array}{l}\text { Scene6: revealing the worries of } \\
\text { pregnant women (nursing care of } \\
\text { women with abnormal pregnancy) }\end{array}$ & $\begin{array}{l}\text { Key points: } 1 \text {. The clinical manifestations } \\
\text { and nursing measures of abnormal } \\
\text { pregnancy were elaborated; } 2 \text {. List } \\
\text { the auxiliary examination methods of } \\
\text { abnormal pregnancy. } \\
\text { Difficulty: skilled nursing operation of } \\
\text { pregnant women with common abnormal } \\
\text { pregnancy. }\end{array}$ & $\begin{array}{l}\text { 1.Task driven method } \\
\text { 2.Case analysis } \\
\text { 3. Role playing }\end{array}$ \\
\hline & $\begin{array}{c}\text { Scene7: revealing the worries of } \\
\text { pregnant mothers (nursing care of } \\
\text { women with specific diseases during } \\
\text { pregnancy) }\end{array}$ & $\begin{array}{l}\text { Key points: } 1 \text {. Master the nursing } \\
\text { measures of gestational hypertension and } \\
\text { gestational diabetes mellitus; } 2 \text {. Clinical } \\
\text { manifestations and treatment principles of } \\
\text { gestational hypertension and gestational } \\
\text { diabetes mellitus. } \\
\text { Difficulties: } 1 \text {. Clinical manifestations } \\
\text { and treatment principles of gestational } \\
\text { hypertension and gestational diabetes } \\
\text { mellitus; } 2 \text {. The interaction between } \\
\text { diabetes and pregnancy, delivery and } \\
\text { puerperium }\end{array}$ & $\begin{array}{l}\text { 1.Task driven method } \\
\text { 2.Teaching method } \\
\text { 3.Research on group } \\
\text { cooperation training }\end{array}$ \\
\hline
\end{tabular}




\begin{tabular}{|l|c|c|c|}
\hline & & $\begin{array}{c}\text { Key points: 1. Common pregnancy } \\
\text { complications and the interaction among } \\
\text { pregnancy, delivery and puerperium. }\end{array}$ & $\begin{array}{c}\text { 1.Teaching method } \\
\text { Scene8: revealing the worries of } \\
\text { pregnant mothers (nursing care of } \\
\text { women with pregnancy complications) }\end{array}$ \\
$\begin{array}{c}\text { 2. Clinical manifestations and nursing } \\
\text { measures of pregnancy complications. } \\
\text { Difficulties: 1. Identify common } \\
\text { pregnancy complications. 2. Carry out } \\
\text { propaganda and education. }\end{array}$ & $\begin{array}{l}\text { 2.Task driven method } \\
\text { cooperation training }\end{array}$ \\
\hline
\end{tabular}

\section{Implementation and Effect of Classroom Teaching}

Teaching Design Ideas: The teaching design is based on the analysis of learning situation which is gotten by big data analysis method, cognitive law of higher vocational students and industry orientation. 1: integrated teaching, this course adopts integrated teaching, takes the post demand as the classroom logic, combines theory with practice, so that students can learn by doing, practice in learning, and master knowledge and skills. 2: Double subject teaching, course teaching module, on campus and off campus training, practice together. School learning and job needs are seamlessly linked. That is: three stages of classroom teaching, preview before class, knowledge navigation, practice in class, knowledge consolidation, after class expansion, knowledge extension, learning for application, improve ability. This model highlights the progressive cultivation with students as the center, industry post skills as the basis, students' learning achievements as the guidance and ideological and political education as the soul. This teaching mode realizes "three highs" of teaching effect, that is, high participation of students, high timeliness of learning process, and high personalization of learning results [9].

\section{Teaching Implementation Process}

Overall Curriculum Implementation: The teaching process can be divided into three stages: guidance before class, practice in class and development after class. Based on the teaching plan, the teaching activities strengthen the communication between students and teachers by means of information-based teaching. The information dissemination is timely and the distance between teachers and students is shortened. Through the comprehensive and continuous feedback, the evaluation and implementation of the whole teaching classroom and course teaching can complete a complete evaluation and diagnosis closed loop in the three stages of the teaching process “"Learning to practice in class" is carried out with students as the main body and teachers as the guide. Each independent classroom is divided into four links of "leading people, entering and winning" (Table 3). Although this course focuses on adapting to clinical needs, it is impossible to include a large amount of knowledge in one class. Therefore, we focus on each class. Now to explore the baby's Secret "abdominal four step palpations" as an example to show the four links. The first key word of classroom promotion is "lead", that is, knowledge navigation. In this link, the teacher leads out the knowledge points of the course by cases, videos, high-quality questions, etc. The second key word of classroom promotion is "people". In this link, the main body of the classroom is students. The teacher manages the classroom as a scaffold.

Table 3: "fascinating" four links.

\begin{tabular}{|c|c|c|}
\hline \multirow{6}{*}{ 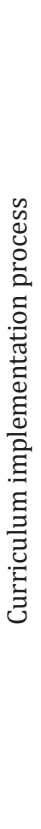 } & $\begin{array}{l}\text { Key words: } \\
\text { Guide(5min) }\end{array}$ & $\begin{array}{l}\text { The case was introduced and the question was raised: “what communication should nurses have with Ms. Zhang before the } \\
\text { examination?"Fetal delivery mode, fetal exposure, fetal orientation..." to arouse students' thinking, and introduce the learning } \\
\text { of "four step abdominal palpation".It will lead teachers and students to explore together. }\end{array}$ \\
\hline & $\begin{array}{l}\text { Key words: } \\
\text { human (10 min) }\end{array}$ & $\begin{array}{l}\text { In this link, the teacher refines the knowledge points through the classroom introduction, visualizes the abstract and difficult } \\
\text { operation process with the help of video and courseware, and guides the students to break through the key points and } \\
\text { resolve the difficulties.Demonstrate the relevant precautions. }\end{array}$ \\
\hline & $\begin{array}{l}\text { Key words: } \\
\text { into (50 min) }\end{array}$ & $\begin{array}{l}\text { This link takes the task as the driving force, and produces students' learning achievements through information means.In } \\
\text { order to let our students at different levels participate in the classroom, the role of teachers is the key, and teachers are the } \\
\text { steering wheel of this classroom train. By throwing out problems before class, lighting the atmosphere, and taking high- } \\
\text { quality problems as the driving force in class, students can realize the combination of speaking, acting and practicing in class. } \\
\text { Four groups of action demonstration site randomly selected students to complete, allowing the existence of non-standard } \\
\text { action, teachers correct action, increase participation, deepen students' impression of action requirements. Through the } \\
\text { scene exercise, the students are guided to learn four steps of abdominal palpation, to judge the mode of delivery, fetal } \\
\text { presentation, fetal position, and to be proficient in health guidance during pregnancy.Objective: let students participate in the } \\
\text { classroom more, let students learn knowledge from peers. }\end{array}$ \\
\hline & Key words: & $\begin{array}{l}\text { 1.Curriculum development: students show preview results, conduct group mutual evaluation and teacher guidance, } \\
\text { effectively promote learning enthusiasm and enhance learning effectiveness.Knowledge points are the display of points one } \\
\text { by one. In order to use knowledge effectively, we must return knowledge points to the life situation, let students expand } \\
\text { knowledge points to a wide range, and achieve the realm of "winning" in teaching. }\end{array}$ \\
\hline & & $\begin{array}{l}\text { 2.Course assessment and achievement display.The case operation drills were carried out in groups, uploaded to the network } \\
\text { teaching platform, and the training courses were displayed after the selection. }\end{array}$ \\
\hline & & ion" through \\
\hline
\end{tabular}


Through the teacher's demonstration, it shows a complete operation process or an independent case analysis, so that students can chain up the knowledge chain from point to area. The third key word of classroom promotion is "entering". In this link from "people" to "entering", the classroom initiative turns from teachers to students. Teachers help students to sort out the knowledge chain through the independent inquiry learning mode, sort out the knowledge fragments in the classroom, apply the knowledge points to various clinical situations, think independently and help each other to improve. Students sort out the knowledge chain, sort out the operation points and matters, from the simple memory of the second link to the reappearance and application of the third link knowledge, students repeat learning, active thinking. The fourth key word of classroom promotion is "win". This link is the embodiment of learning achievements. Through the climbing of learning process, students and teachers grow together in the classroom, and teaching and learning are mutually beneficial [10].

Course Fragment Design: Taking the Course of Four Step Palpation of Abdomen as An Example

The teaching difficulty of this course lies in the operation method of abdominal four step palpation, and the judgment of fetal delivery mode, fetal presentation and fetal position. This class is divided into three stages (diagnosis closed loop) of pre class guidance, learning practice and after class development, with a total of 2 class hours. Guidance before class. Before class, teachers publish the preview materials to the information-based teaching platform and push them to the wechat end of students' mobile phones. The teacher analyzed the preview results, understood that the students' judgment on the mode of delivery, fetal presentation and fetal position was weak, and they had a good grasp of the purpose of abdominal four step palpation, and finally determined the teaching plan [11].

After Class Development: After class exercises were pushed through the teaching platform which si established by big data system, and the after-class exercises were mainly based on the real questions of nurses' qualification examination to prepare for the students' nurses' qualification examination. Answer questions in WeChat group, shorten the distance between teachers and students, and break the time and space restrictions of the classroom. Relevant knowledge is released through the platform of student associations, and professional associations organize knowledge and skills competitions.

\section{Teaching Evaluation}

The three-dimensional evaluation promotes the effectiveness, through students' self-evaluation, students' mutual evaluation and teachers' comments, The big data system is used to collect the above three-dimensional evaluation information, the three-dimensional degree can understand the knowledge mastering situation, at the same time, through role perception and mind map, summarize the learned knowledge, cultivate students' ability to build a systematic and rigorous knowledge structure, and promote students' learning effectiveness. The assessment of students' performance should change the traditional single assessment method of theoretical knowledge, pay attention to the comprehensive assessment of students' learning attitude, thinking ability, practical ability and problem-solving ability, and objectively evaluate the students' learning situation. Curriculum assessment is closely related to medical practice, and knowledge and skills are consistent with the national nurse qualification certificate assessment, higher vocational education personnel training mode and $1+\mathrm{X}$ certificate system. The assessment subjects are diversified. The evaluation data adopts wide-angle evaluation, including students' selfevaluation, group mutual evaluation, course teacher's comments, and clinical teaching teacher's comments, striving for multi angle evaluation and multi angle improvement from knowledge to skills, skills to ability [12].

\section{Implementation Effect}

This teaching mode realizes the "three highs" of teaching effect, that is, high participation of students, high timeliness of learning process and high personalization of learning results. Students' participation is high. The whole classroom teaching is completed in the environment of integration of theory and practice, which promotes students' participation and self-confidence, and improves their ability of knowledge transfer and application. Compared with the traditional teaching, the effect of teaching reform is obvious. The efficiency of learning process is high. The teaching process is streamlined, and the diagnosis closed loop is formed. The efficient teaching implementation has been achieved, and the basic teaching objectives have been basically achieved. Learning outcomes are highly personalized. In and out of class, students are encouraged to discover and develop their own interests and expertise. Students actively participate in personalized learning results display and exchange activities and enhance their learning initiative and initiative.

\section{Teaching Characteristics and Reflection}

Since January 2014, we have been carrying out the practical research on the curriculum reform of Obstetrics and gynecology nursing in Higher Vocational Colleges Based on the OBE education concept from the perspective of big data. We have been deepening the reform, the teaching effect has been continuously improved, and the students' ability has been continuously improved [13]. Before the teaching reform, the average score of Obstetrics and gynecology nursing course was only (73.94 $1 \pm$ After the reform, the average final score of each semester was (88.72 10.60) \pm Through big data analysis, students' satisfaction with the course was 90.41 points, which were higher than that before the implementation 
of the reform. The students' passing rate of the examination was significantly improved, and their learning initiative and enthusiasm were also greatly improved. According to the comparison between (Table 4) (assessment of Obstetrics and gynecology nursing in June 2014 - before the education reform) and (Table 5) (assessment of Obstetrics and gynecology nursing in the second semester of 2020-2021 academic year - after the education reform), We get the following conclusions: from the perspective of big data, based on the OBE education concept, the practical research on the curriculum reform of Obstetrics and gynecology nursing in higher vocational colleges has greatly improved students' mastery of the knowledge points and operation skills of Obstetrics and gynecology nursing, greatly improved their autonomous learning ability, and cultivated students' lifelong learning ability.

Table 4: Assessment of Obstetrics and gynecology nursing in June 2014 (before education reform).

\begin{tabular}{|c|c|c|c|c|c|c|c|c|c|c|}
\hline Teaching Class & \multicolumn{2}{|c|}{$\begin{array}{l}13 \text { Grade Nursing } \\
\text { Classes 1-6 }\end{array}$} & \multicolumn{2}{|c|}{ Total Students } & \multicolumn{2}{|c|}{300} & \multicolumn{2}{|c|}{$\begin{array}{c}\text { Total Expected } \\
\text { Learning Outcomes }\end{array}$} & \multicolumn{2}{|c|}{5} \\
\hline $\begin{array}{c}\text { Grade } \\
\text { NO-Proportion }\end{array}$ & \multicolumn{2}{|c|}{$\geq 90$} & \multicolumn{2}{|c|}{$[80,90)$} & \multicolumn{2}{|c|}{$[60,80)$} & \multicolumn{2}{|c|}{$<60$} & \multicolumn{2}{|c|}{$\begin{array}{c}\text { Abnormal } \\
\text { Assessment }\end{array}$} \\
\hline Learning outcomes & No. & Per. & No. & Per. & No. & Per. & No. & Per. & No. & Per. \\
\hline SOC1 & 45 & 15 & 60 & 20 & 150 & 60 & 15 & 5 & 0 & 0 \\
\hline SOC2 & 42 & 14 & 63 & 21 & 186 & 62 & 15 & 5 & 0 & 0 \\
\hline SOC3 & 30 & 10 & 75 & 25 & 186 & 62 & 15 & 5 & 0 & 0 \\
\hline SOC4 & 42 & 14 & 63 & 21 & 186 & 62 & 15 & 5 & 0 & 0 \\
\hline SOC5 & 30 & 10 & 60 & 20 & 150 & 50 & 60 & 20 & 0 & 0 \\
\hline final exam & 36 & 12 & 69 & 23 & 186 & 62 & 9 & 3 & 0 & 0 \\
\hline Course comprehensive score & 42 & 14 & 63 & 21 & 183 & 61 & 12 & 4 & 0 & 0 \\
\hline
\end{tabular}

(Notes: No.=Number, Per.=Percentage)

Table 5: Assessment of Obstetrics and gynecology nursing in the second semester of 2020-2021 academic year (the latest year after the education reform).

\begin{tabular}{|c|c|c|c|c|c|c|c|c|c|c|}
\hline Teaching Class & \multicolumn{2}{|c|}{$\begin{array}{l}\text { 19grade Nursing } \\
\text { Classes 1-6 }\end{array}$} & \multicolumn{2}{|c|}{ Total Students } & \multicolumn{2}{|c|}{300} & \multicolumn{2}{|c|}{$\begin{array}{c}\text { Total Expected } \\
\text { Learning Outcomes }\end{array}$} & \multicolumn{2}{|c|}{5} \\
\hline $\begin{array}{c}\text { Grade } \\
\text { NO-Proportion }\end{array}$ & \multicolumn{2}{|c|}{$\geq 90$} & \multicolumn{2}{|c|}{$[80,90]$} & \multicolumn{2}{|c|}{$[60,80]$} & \multicolumn{2}{|c|}{$<60$} & \multicolumn{2}{|c|}{$\begin{array}{l}\text { Abnormal } \\
\text { Assessment }\end{array}$} \\
\hline Learning outcomes & No. & Per. & No. & Per. & No. & Per. & No. & Per. & No. & Per. \\
\hline SOC1 & 38 & 16.3 & 95 & 40.4 & 99 & 42.1 & 3 & 1.2 & 0 & 0 \\
\hline SOC2 & 45 & 19.2 & 98 & 41.7 & 90 & 38.3 & 2 & 0.8 & 0 & 0 \\
\hline SOC3 & 52 & 22.1 & 105 & 44.7 & 77 & 32.8 & 1 & 0.4 & 0 & 0 \\
\hline SOC4 & 60 & 25.5 & 136 & 57.9 & 39 & 16.6 & 0 & 0 & 0 & 0 \\
\hline SOC5 & 90 & 30 & 90 & 30 & 120 & 40 & 0 & 0 & 0 & 0 \\
\hline final exam & 60 & 25.5 & 136 & 57.9 & 39 & 16.6 & 0 & 0 & 0 & 0 \\
\hline Course comprehensive score & 75 & 32 & 118 & 50 & 42 & 18 & 0 & 0 & 0 & 0 \\
\hline
\end{tabular}

(Notes: No.=Number, Per.=Percentage)

Especially, From May 2021 to now, during the New Coronavirus epidemic in Guangzhou, we used the big data system to carry out online teaching, uploading a large number of teaching video screens, chapters of the target test questions and comprehensive exercises to the database, and set the teaching video screen as playback status in the database, so that students can use fragmented spare time to learn repeatedly. Master the key and difficult points thoroughly. The teaching effect is greatly improved. Teachers use the big data system to arrange a large number of extracurricular research topics and course papers and require students to use the Internet and big data to search for information in the system. Students can make full use of big data system and computer network system for conscious learning, in-depth learning, and complete course papers and research topics, which greatly improves students' scientific research and innovation ability and cultivates students' pioneering spirit. It creates a new mode of Higher Vocational Education from "teachers want students to learn" to "students are willing to learn", which lays a solid foundation for higher vocational education to cultivate more and better high skilled talents to meet the needs of society, and makes due contributions to the development of nursing and Health Management College of Guangdong Lingnan vocational and technical college, At the same time, it has also explored some experience reference for the higher vocational colleges of nursing medicine, which benefit more students, teachers and colleges. 
Therefore, from the perspective of big data, the practical research on curriculum reform of Obstetrics and gynecology nursing in Higher Vocational Colleges Based on OBE education concept has created great social benefits.

The starting point of education is not knowledge, but people, and it is the object of our education.0be teaching concept is student-centered, based on the learning background to set up courses, from curriculum design, curriculum implementation, curriculum evaluation, and through the results of reverse design courses, modify the classroom implementation, form an effective classroom teaching closed loop, so as to implement the curriculum objectives, realize the requirements of five major learning areas of professional talent training. The curriculum reform of Obstetrics and gynecology nursing based on OBE education concept is based on the "123 teaching mode" of work study combination based on the analysis of learning situation, cognitive law of higher vocational students and industry orientation. This model highlights the progressive cultivation with students as the center, industry post skills as the basis, students' learning achievements as the guidance and ideological and political education as the soul. This teaching mode realizes the "three highs" of teaching effect, that is, high participation of students, high timeliness of learning process and high personalization of learning results. The teaching process can be divided into three stages: guidance before class, practice in class and development after class. Each teaching link has assessment and diagnosis, which provides reference data for the next link.

Through the comprehensive continuous evaluation and feedback, the evaluation implements the whole teaching classroom and course teaching, so that the three stages of the teaching process complete a complete evaluation and diagnosis closed loop. Through knowledge learning, school skills practice, clinical skills observation and internship, clinical hospital internship progressive extended learning space, multi angle and multi-level cultivation of students' clinical comprehensive quality and nursing professional quality. From simulated training to feeling the relatively real work scene, observing the clinical operation process to using skills to solve practical clinical problems, the separation between classroom learning and post, progressive extension of learning space and zero gap connection between major and post have been solved [13]. Education is a subject that is constantly being revised, just like the endless curriculum reform. The introduction of OBE teaching concept, through the feedback of learning results to modify the classroom. In the course reform, we find that the new generation of students have unlimited potential, unlimited creativity, and each has its own characteristics. The significance of education is to respect each individual's progress and personality. Therefore, we are still thinking about how to refine the measurement standard of learning outcomes, further humanize and personalize the quantitative results, and respect each individual learning process and output.

\section{Summary}

Finally, it should return to our teaching goal: from professional knowledge to methods and abilities, and finally reflect the students' social adaptability and ability to produce gradient climbing. Any teaching method is not an isolated way, it needs absorb anything and everything. Any kind of teaching method is not only suitable for a course, but also can be copied and improved, and suitable for more subjects; Any kind of teaching method is not only aimed at a certain group of people, but it should also be adjusted through "teaching students in accordance with their aptitude", so that more students can use it and produce greater learning influence. In the theme of education, students should pay attention to their interests; Starting from the major, students should pay attention to it; Starting from emotion, arouse students' resonance [14]. From the perspective of big data, based on the OBE education concept, a series of reforms of Obstetrics and gynecology nursing courses in higher vocational colleges have been carried out for many years. The practice shows that the knowledge and skills of Obstetrics and Gynecology Nursing of higher vocational college students have been improved rapidly, their ability to analyze and solve problems has been greatly strengthened, their graduates are more popular in the society, and the popularity and reputation of higher vocational colleges have been improved, The number of students registered for Guangdong Lingnan Institute of Technology is also increasing year by year, forming a virtuous circle, which promotes the further development of College of nursing and health of Guangdong Lingnan Institute of Technology.

Therefore, it is very urgent to continue to promote a series of reform of Obstetrics and gynecology nursing curriculum in Higher Vocational Colleges Based on OBE education concept from the perspective of big data, and keep pace with the times, constantly promote the achievements and experience of teaching reform, and promote the teaching reform to a deeper and broader direction. In particular, how to make good use of the Internet for Teaching Reform [14], how to make better use of big data to carry out indepth teaching reform research of Obstetrics and gynecology nursing course in Higher Vocational Colleges Based on OBE education concept from the perspective of big data are our future efforts.

\section{Acknowledgments}

This work was supported by a grant from The research and practice of multi collaborative talent training program under the background of the coexistence of multiple enrollment channels in Vocational Colleges under the project of Guangdong Higher Vocational Education Research Association in 2019 (No: gdgz19y117)". 


\section{References}

1. Xiang Keheng, Shi Changyan (2021) Short video live broadcasting talents in Higher Vocational Colleges under the guidance of "class competition integration". Modern business industry (11) 69-71.

2. (2019) Research and practice of peer teaching mode under the guidance of students' learning achievements. Huang Shanshan; Evidence based nursing 2019(05): 452-453.

3. Guo Huili, Miao xiuxin, Zhang Meihua (2015) Application effect of case teaching method in nursing graduate class. Qilu Nursing Journal (24): $18-120$.

4. Yin Ming, Liu Danqing, ZHENG Jichang (2016) Review of DQP. China Vocational and technical education, 2016, issue 6.

5. He Jierong (2021) Exploration on curriculum reform of Obstetrics and Gynecology Nursing [J]. Heilongjiang science (03): 132-133.

6. Ren Feng, Li Jian, Chang Haimin, Zhang Jinhua (2014) Application of case teaching method combined with peer mutual learning method in basic nursing teaching. Journal of Xinxiang Medical College 07(8): 590-591

7. Hao ping, Cui Rong, Wang yanru (2013) Effect evaluation of case teaching method in the teaching of nursing nutrition. Journal of nursing education 28(16): 1505-1507.

8. Qing Zhong, Shaozao Tan, Huifang Chen, Liujun Shi, Fei Zan, et al. (2020) Dual-function antibacterial micelle via self-assembling block copolymers with various antibacterial nanoparticles. ACSOmega 5(15): 8523-8533.

\section{ISSN: 2574-1241}

DOI: 10.26717/BJSTR.2021.37.005974

Huifang Chen. Biomed J Sci \& Tech Res

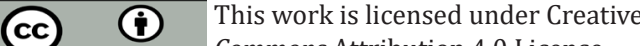

Commons Attribution 4.0 License

Submission Link: https://biomedres.us/submit-manuscript.php
9. Yiwei Wang, Huifang Chen, Shanshan Shi, Sha Wu, Ruijie Meng, et al. (2021) Deficiency of NEIL3 enhance the chemotherapy resistance of prostate cancer. International Journal of Molecular Sciences.15 April 22(8): 4098

10. Xiao chunfen, Chen Huifang (2015) Synthesis and antitumor activity of novel 3-arylcoumarins. Synthetic chemistry 6: 78-84

11. Huifang Chen (2014) Does School Enterprise Cooperation to Promote Students' Occupation Career Planning:on the Inspirational Experience of School-enterprise Cooperation from Developed Countries.Review of Global Academics 1(2): 146-152.

12. Yang Nie, Huifang Chen (2020) Effect of Total Flavonesin Clematis Filamentosa Dunn against Myocardial Ischemia Reperfusion Injury by Adjusting Autophagy in Rats. Issue title:Proceedings of the 2020 International Symposium on Artificial Intelligence in Medical Sciences. ISAIMS 140-146.

13. Hua Cao, Huifang Chen, Yiting Tu, Peilin Zheng, Jianhua Yi, et al. (2021) In-depth Study of Pharmacology Teaching Reform Based on Ability Training under the Framework of American DQP. IOP Conference Series: Earth and Environmental Science (EES) (Online ISSN: 1755-1315 Print ISSN: 1755-1307). 4098: 8-18.

14. Li Wang, Yang Nie, Huifang Chen, Jun Sun, Mingyue Hu, et al. (2021) A Network Pharmacology Approach to Investigate the Underlying Mechanisms of Alpinia Katsumadai Hayata on Acne Vulgaris. China pp. 135-147.

$\begin{array}{ll}\text { BIOMEDICAL } & \text { Assets of Publishing with us } \\ \text { RESEARCHES } & \text { - Global archiving of articles } \\ \text { - Immediate, unrestricted online access } & \text { - Rigorous Peer Review Process } \\ & \text { - Authors Retain Copyrights } \\ & \end{array}$

